\title{
APPRAISING THE NONEXISTENT: THE DELAWARE COURTS' STRUGGLE WITH CONTROL PREMIUMS
}

\begin{abstract}
William J. CARneY ${ }^{\dagger} \&$ MARK Heimendinger $^{\dagger \dagger}$
The Delaware Supreme Court has concluded that under the Delaware appraisal statute, dissenting shareholders are entitled to the pro rata value of their firm and that the market price of any firm's stock reflects an implicit minority discount from its pro rata value. Thus, to ensure that dissenting shareholders are properly compensated, the Delaware courts have been adding a "control premium" to firm values. As we will demonstrate, this doctrine has resulted in inflated awards to dissenting shareholders, for if the conclusion of the Delaware Supreme Court that market prices do not include a control premium is correct, it does not follow that dissenting shareholders must be paid a premium, and if the conclusion is incorrect, then the theoretical support for paying a premium disappears.
\end{abstract}

\section{INTRODUCTION}

Appraisal proceedings have hardly been the Delaware courts' finest moments. For decades, these courts eschewed evidence based on widely accepted finance methodology, holding instead that determinations of value were questions of law and not fact. ${ }^{1}$. It was not until 1983 that the Delaware Supreme Court permitted the introduction of evidence obtained through modern valuation methods. ${ }^{2}$ While the

${ }^{\dagger}$ Charles Howard Candler Professor, Emory University School of Law.

${ }^{+\dagger}$ Associate, Milbank, Tweed, Hadley \& McCloy, New York.

We wish to thank Michael Knoll, Roberta Romano, Jon Macey, Robert Ahdieh, the participants at the Symposium on Control Transactions at the University of Pennsylvania Law School on February 9, 2003, and the participants at an Emory Law School Faculty Colloquium on March 26, 2003.

See, e.g., Francis I. duPont \& Co. v. Universal City Studios, Inc., 312 A.2d 344, 348 (Del. Ch. 1973) ("It is established Delaware law that for appraisal purposes earnings are to be determined by averaging the corporation's earnings over a reasonable period of time."), aff'd, 334 A.2d 216 (Del. 1975). For a criticism of the former "Delaware Block" methodology, see David Cohen, Comment, Valuation in the Context of Share Appraisal, 34 EMORY L.J. 117 (1985), which concludes "that the Delaware block method is inconsistent with modern valuation theory and that, in general, the stock market price supplies the most essential ingredient in an enlightened approach to share appraisal." Id. at 119.

${ }^{2}$ See Weinberger v. UOP, Inc., 457 A.2d 701, 712-13 (Del. 1983) (declaring the "Delaware Block" or weighted average method to be "clearly outmoded" and stating that subsequent appraisals "must include proof of value by any techniques or methods which are generally considered acceptable in the financial community"). 
current methodology is generally market-based, the courts nevertheless continue to speak of value in ways that show a deep misunderstanding of valuation methodology and a distrust of market values. ${ }^{3}$ Indeed, the Delaware Supreme Court has stated that the market price of shares may not be representative of true value. ${ }^{4}$ In Smith $v$. Van Gorkom, ${ }^{5}$ the Delaware Supreme Court criticized a board that relied on a $46 \%$ premium over the market because it was uninformed about "intrinsic value." More recently, the Delaware Supreme Court rejected an appraised valuation that was $200 \%$ above the pre-transaction market value on the basis that the "trial court's decision to reject the addition of a control premium ... placed too much emphasis on market value." The court criticized the chancery court's valuation as too low because it failed to add a control premium to the market price of comparable companies to reach the asserted value of the whole firm, choosing instead to use the "discounted" market price of a small block of shares in the trading market. ${ }^{8}$ The pre-announcement market price was $\$ 17.25$; $^{9}$ the consideration paid in the cash-out merger was worth approximately $\$ 28 ;^{10}$ the appraised value initially determined by the chancery court was $\$ 51 ;{ }^{11}$ and the final value awarded

${ }^{3}$ While the market value of a company's stock does not necessarily accurately estimate that company's future cash flows, the Efficient Capital Markets Hypothesis $(E C M H)$ demonstrates that a certain deference needs to be given to market value. See RICHARD A. BREALEy \& STEWART C. MYERS, PRINCIPLES OF CORPORATE FinanCE, 369-70 (6th ed. 2000) (cautioning management to pay attention to market values in a subchapter entitled "The Six Lessons of Market Efficiency"). We urge courts to heed this advice.

${ }^{4}$ See Paramount Communications, Inc. v. Time, Inc., 571 A.2d 1140, 1150 n.12 (Del. 1989) (" $[\mathrm{I}] \mathrm{t}$ is not a breach of faith for directors to determine that the present stock market price of shares is not representative of true value or that there may indeed be several market values for any corporation's stock."). Whether or not this statement is true, the court fails to suggest any of the reasons for this shortcoming, such as the existence of material nonpublic information. See Daniel R. Fischel, Market Evidence in Corporate Law, 69 U. CHI. L. REV. 941, 941 (2002) (arguing "that courts should rely more heavily on market prices when resolving valuation disputes").

${ }^{5} 488$ A.2d 858 (Del. 1985).

${ }^{6}$ Id. at $874-76$. This misguided search for the holy grail of intrinsic value began with Tri-Continental Corp. v. Battye, 74 A.2d 71 (Del. 1950), which defined the "value of stockholders proportionate interest" as "the true or intrinsic value of his stock." Id. at 72.

${ }^{7}$ Rapid-Am. Corp. v. Harris, 603 A.2d 796, 806 (Del. 1992).

${ }^{8} I d$. at 804-05.

${ }^{9}$ Harris v. Rapid-Am. Corp., No. 6462, 1992 Del. Ch. LEXIS 75, at *7 (Del. Ch. Apr. 1, 1992).

${ }^{10}$ Harris v. Rapid-Am. Corp., No. 6462, 1990 Del. Ch. LEXIS 166, at*3 (Del. Ch. Oct. 2, 1990).

${ }^{11} I d$. at $* 52$. 
after remand, including the control premium, was $\$ 73.29 .^{12}$ If a shareholder purchased shares immediately before the announcement, the gain was $325 \%$. This bizarre result has received relatively little attention, except to the extent that it has become an accepted part of Delaware law. ${ }^{13}$ While the Delaware courts appear to believe they are using the science of financial economics in their valuation efforts, their misunderstandings have led to windfalls for dissenting shareholders.

George Stigler once said that one should have a license to practice economics; $;^{14}$ Fred McChesney repeated that caution with respect to law professors attempting to practice it, ${ }^{15}$ and yet, courts are forced by necessity to engage in economic valuation. ${ }^{16}$ This reality necessitates that those who criticize must provide constructive criticism.

Received wisdom in Delaware corporate law now seems to understand that stock market prices are inaccurate in a way that cannot be tested empirically. ${ }^{17}$ This wisdom holds that in nearly all cases the

${ }^{12}$ Harris, 1992 Del. Ch. LEXIS 75, at *13.

13 But see Richard A. Booth, Minority Discounts and Control Premiums in Appraisal Proceedings, 57 BUS. LAw. 127, 128 (2001) (arguing "that the addition of a control premium is inconsistent with settled corporation law and good policy that there is no basis for the assumption that market prices routinely build in a minority discount").

${ }^{14}$ George Stigler, The Theory of Economic Regulation, BELL J. ECON. \& MGMT. SCI., Spring 1971, at 3, 18.

${ }^{15}$ See Fred S. McChesney, Economics, Law, and Science in the Corporate Field: A Critique of Eisenberg, 89 COLum. L. REv. 1530, 1547-48 (1989) (emphasizing that, while "economists cannot practice law," corporate law scholars can enter the field of economics "without training or examination" and noting that "[a]lthough a few corporate lawyers make good economists, most do not" (citing George J. Stigler, Occupational Licensure for Economists?, in OCCUPATIONAL LICENSURE AND REGULATION 348 (Simon Rottenberg ed., 1980))).

${ }^{16}$ The Delaware courts, in considering expert testimony in this area, are bound by Delaware's version of Federal Rule of Evidence 702. DEL. R. EVID. 702. Delaware has followed the U.S. Supreme Court's holdings in this area, that a trial judge must "'ensure that any and all scientific testimony ... is not only relevant, but reliable." M.G. Bancorporation, Inc. v. Le Beau, 737 A.2d 513, 521 (Del. 1999) (quoting Daubert v. Merrell Dow Pharm., Inc., 509 U.S. 579, 589 (1993)). In this sense, Delaware courts are inevitably drawn into difficult judgments of scientific expertise.

${ }^{17}$ Studies of control purchases provide ample evidence that control premiums exist. For examples, see Bernard S. Black, Bidder Overpayment in Takeovers, 41 STAN. L. REv. 597 (1989); Lawrence A. Hamermesh, Premiums in Stock-for-Stock Mergers and Some Consequences in the Law of Director Fiduciary Duties, 152 U. PA. L. REV. 881 (2003); Michael Jensen \& Richard Ruback, The Market for Corporate Control: The Scientific Evidence, $11 \mathrm{~J}$. FIN. ECON. 5 (1983). But the point is that while the value of a company may reflect the expected value of a known potential transaction, control premiums do not simply inhere in the value of all companies. A value-creating control transaction is simply too low a probability event for most firms. 
market value of stock in any publicly traded company is merely the value of a minority interest which necessarily reflects a minority discount. ${ }^{18}$ This reasoning denies that the value of an entire company is simply the market value of its equity plus the market value of its debt. The Delaware courts have accepted this wisdom and have rejected the "aggregate market value" approach to valuing shares of a company in an appraisal proceeding. Under Delaware's current approach, the value of the company as a going concern must include that element of value known as the control premium. ${ }^{19}$ This approach poses a fundamental challenge to the "law of one price," which asserts that arbitrage will tend to trade away any difference between price and economic value. ${ }^{21}$

We argue that both the received wisdom and the Delaware approach contain fundamental misconceptions about value. In addition, the Delaware approach creates conflicts in the way minority shareholders are treated in various forced-sale situations (e.g., stockfor-stock mergers and at least some reverse stock splits) that can only be reconciled by rejecting the notion that control premiums inhere in the values of all companies.

Part $\mathrm{I}$ is the doctrinal section of this Article. It reviews the Delaware cases that have adopted a "control premium" approach to valuation. We argue that these decisions have misread earlier precedents that required a firm to be valued as a going concern-with all its warts-rather than at a higher liquidation value that would have eliminated agency costs or at a post-transaction value that would have assumed potential synergies from a hypothetical (and thus speculative) business combination.

${ }^{18}$ See, e.g., Rapid-Am. Corp. v. Harris, 603 A.2d 796, 806 (Del. 1992) (stating that the "exclusion of a 'control premium' artificially and unrealistically treated Rapid as a minority shareholder"); Le Beau v. M.G. Bancorporation, No. 13414, 1998 Del. Ch. LEXIS 9, at *25 (Del. Ch. Jan. 29, 1998) (determining that an expert witness's capital market valuation approach included a "built-in minority discount"). Interestingly, this same wisdom does not apply to the market value of debt so that, in determining a company's equity value, a court is free to subtract only the market value of debt from the value of the firm even if such debt is trading at a discount. Rapid-Am., $603 \mathrm{~A} .2 \mathrm{~d}$ at 804.

19 Infra notes 66-67 and accompanying text.

${ }^{20}$ See BREALEY \& MYERS, supra note 3, at $796 \mathrm{n} .8$ (defining the "law of one price" as the purchasing power parity principle applied to the price of a single good).

Id. at $38 \& \mathrm{n} .3$. This also poses a challenge-correct or not-to the general acceptance by much of the academic literature of ECMH, which according to some is one of the most well established hypotheses in all the social sciences. See, e.g., Michael Jensen, The Takeover Controversy: Analysis and Evidence, 4 MIDLAND CORP. FIN. J., Summer 1986, at 6, 11. 
Part II reviews the literature that argues for the addition of a control premium to the stock price of every publicly traded company. We demonstrate that the basis for this argument is not supported by the presently available evidence. Control premiums are only paid when a bidder perceives that a purchase of control is worthwhile-where there are gains from trade. Moreover, despite the claims of the Delaware courts and some commentators, there are not multiple and separate markets for shares of firms (e.g., trading markets for small blocks and a separate market for corporate control). We expressly exclude consideration of a control premium in second stage takeout mergers, where a control premium has already been paid. We should emphasize that our enterprise is quite limited: we only address the imputation of a control premium in freeze-out mergers where there is no related control transaction.

Part III relaxes the assumption of efficient capital markets and reviews the fairness arguments that revolve around the disparate treatment of shareholders. We explain that these arguments are rejected either by evidence of ex ante payments or the widespread availability of contractual arrangements to allocate the receipt of control premiums. Accordingly, if public investors discount the price they pay for shares to reflect their lack of control over firm policies and agency costs, then compensating them on the basis of the same "minority discount" is not unfair. In other words, shareholders who receive the market value of their shares either through appraisal or selling into the market, generally, get what they paid for.

Finally, Part IV analyzes the structure and language of Delaware's appraisal statute to show that it contemplates paying minority shareholders for what they owned, and that this provides them with full compensation. Here, we show that where market exceptions to appraisal are present, shareholders will always receive as "fair value" the market price with its claimed "minority discount," rather than receive a control premium. To pay more when appraisal is available not only provides those shareholders with a windfall at the expense of the majority, but also creates a conflict in Delaware corporate law. The Delaware Supreme Court's approval of market value as fair value in a recent reverse stock split that eliminated small shareholders highlights the conflict with its use of control premiums in other areas.

Ultimately, we urge courts to presume that market value is the best measure of fair value. The burden should then be placed on dissenting shareholders to prove why and to what extent market value is 
inadequate. We believe this would improve the accuracy of appraisal valuations and at the same time achieve judicial economies.

\section{Delaware's Treatment of Control Premiums}

We begin by tracing how the Delaware courts first rejected the notion of any premium over "going concern value" that might result from a sale or liquidation and then used that same going concern doctrine to conclude that a share was always worth less than its pro rata share of the value of the going concern. The logic of the "going concern" doctrine simply cannot bear this burden. Nonetheless, while denying that any speculative elements of value should be employed, the courts have reached the point where a control premium has become an integral part of the value of every going concern, regardless of how speculative such a control premium might be.

\section{A. Rejection of Market Values}

Delaware's current control premium confusion began with Chicago Corp. v. Munds, ${ }^{22}$ the first Delaware Chancery Court decision to analyze the definition of "value.," While the court concluded, when speaking of the dissenting shareholder, that " $[w]$ hat he is deprived of is what he should be paid for," ${ }^{24}$ the court's analysis of why market value is not a sufficient arbiter of "value" created a precedent that survives to this day.

The court based its decision primarily on two arguments: (i) although the version of the Delaware statute in effect at the time of the decision was modeled on a New Jersey statute, it rejected the term "market value" as used in the New Jersey statute and instead used the term "value," of value because a merger would "destroy [a company's] individual identity and wipe[] out of existence all the stock of [its] kind," thus rendering impossible any replacement in the market. ${ }^{26}$

22172 A. 452 (Del. Ch. 1934).

${ }^{23}$ Id. at 453-57. Note that at this time the statute simply used the term "value" rather than "fair value." Id. at 453 (quoting DEL. REv. CODE, § 1975 (1915), amended by 35 Del. Laws ch. 85, $\S 20$ (1927)). Our account differs from that of Richard Booth, who outlines a short history of premiums in appraisal and contrasts discounts and the law of appraisal in and outside of Delaware. Booth, supra note 13, at 132-45.

${ }^{24}$ Chicago Corp., 172 A. at 455.

${ }^{25}$ Id. at 454-55.

${ }^{26} I d$. at 456 . This predates and is inconsistent with both portfolio theory and the Capital Asset Pricing Model (CAPM), with its conclusion that a stock's rate of return is 
The court did note that market values were sometimes valid for items such as chattel and stock in a company not set to merge, since, if paid the market value, an individual "could easily step into the market and replace presumably at the quoted prices the chattels [sic] or stock which the defendant converted." 27 Nevertheless, the court ruled that the only way the plaintiff could be made whole was to give him the "intrinsic value" of his shares. ${ }^{28}$ While this decision predates modern portfolio theory, ${ }^{29}$ it set a precedent for the focus on "intrinsic value" and wrongly concluded that each company's stock is a unique financial asset. It is understandable that a court in 1934 might not understand how fungible any one share is in a diversified portfolio; however, it is remarkable that the court's conclusion, based on this misunderstanding-that "intrinsic value" diverges from (and is presumably greater than) market value in some systematic way-continues to this day.

set by its systematic risk, i.e. its beta, and that firm-specific risk of a stock is irrelevant to rational, diversified investors. See BREALEY \& MYERS, supra note 3, 195-203 (discussing the relationship between risk and return under the rubric of CAPM). In this context, all stocks with the same beta become substitutes for each other in a well-diversified portfolio. Id. at 199-201.

${ }^{27}$ Chicago Corp., 172 A. at 456.

${ }^{28}$ See id. (“" "[T] he value of the stock" means not merely the market price if the stock is traded in by the public, but the intrinsic value, to determine which all the assets and liabilities must be ascertained."' (quoting Cole v. Wells, 113 N.E. 189, 191 (Mass. 1916))).

${ }^{29}$ See BREALEY \& MYERS, supra note 3, at 187-88 (linking Harry Markowitz's 1952 article, Portfolio Selection, with the birth of modern portfolio theory); Harry Markowitz, Portfolio Selection, 7 J. FIN. 77, 77 (1952) (giving an early perspective on the "second stage" of selecting a portfolio, which "starts with the relevant beliefs about future performances and ends with the choice of portfolio").

${ }^{30}$ See, e.g., Cede \& Co. v. Technicolor, Inc., 758 A.2d 485, 493 (Del. 2000) (“"At present, the statute requires the court to appoint an appraiser who is charged with the obligation of determining the fair or intrinsic value of the stock which is being appraised." (quoting Commentary to H.B. 916, 128th Cen. Assem., 2d Sess. (Del. 1976))); Paskill Corp. v. Alcoma Corp., 747 A.2d 549, 553 (Del. 2000) (noting that value means "true or intrinsic value" (quoting Tri-Continental Corp. v. Battye, 74 A.2d 71, 72 (Del. 1950))); Cinerama, Inc. v. Technicolor, Inc., 663 A.2d 1156, 1166 (Del. 1995) (defining the true value as that which is "determined under the appraisal proceedings" (quoting Cede \& Co. v. Technicolor, Inc., 634 A.2d 345, 371 (Del. 1993))); Cavalier Oil Corp. v. Harnett, 564 A.2d 1137, 1142 (Del. 1989) (“A shareholder who dissents from a cash-out merger is nonetheless entitled to receive the fair or intrinsic value of his shares."); Smith v. Van Gorkom, 488 A.2d 858, 878 (Del. 1985) (finding that directors must assess the intrinsic value of their company before approving a merger). For a skeptical view of intrinsic value, see William J. Carney, Fairness Opinions: How Fair Are They and Why We Should Do Nothing About It, 70 WASH. U. L.Q. 523, 526-27 (1992). 


\section{B. The "Going Concerm" Doctrine}

Subsequently, in Tri-Continental Corp. $v$. Battye, ${ }^{31}$ the Delaware Supreme Court developed the doctrine that a shareholder's interest in a company is a pro rata share of the value of the shareholders' equity in a going concern. ${ }^{32}$ The court did not address either control premiums or minority discounts. Rather, it addressed shares in a closed-end mutual fund that had traded at a discount from the fund's net asset value prior to a merger. ${ }^{33}$ In this context, the court declined to value shares at their net asset value, but instead followed the appraiser's methodology, which constructed a value of the entire fund based on its "fair asset value" and then discounted this value at the same rate that the shares were discounted by the market prior to the merger. ${ }^{34}$ Thus, nothing in the opinion pointed directly toward a control premium, except a possible strained interpretation of dicta in the case. ${ }^{85}$ Essentially, the court held that since shareholders invested in assets the value of which was discounted by virtue of their ownership by a closedend fund (with its presumed agency costs), it was fair to compensate exiting investors in the same way. ${ }^{36}$ We call this the rule of "in at a discount, out at a discount."

The next "going concern" decision was Bell v. Kirby Lumber Corp.," where a huge disparity existed between the net asset value and the market value of a firm. ${ }^{38}$ Once again the court rejected attempts to use net asset value as the measure of value, because the corporation was not liquidating. ${ }^{39}$ Therefore, the court held, the corporation must be valued on a going concern basis and simply quoted its own earlier

${ }^{31} 74$ A.2d 71 (Del. 1950).

Id. at 72 .

${ }^{39}$ Id. at $72-73$.

${ }^{34}$ Id. at 75 .

${ }^{35}$ See id. at 76 ("The conclusion is, therefore, inescapable that the full value of the corporate assets to the corporation is not the same as the value of those assets to the common stockholder because of the factor of discount.").

${ }^{36}$ The reference to diminution of net asset value is our characterization, not the court's. For studies documenting the phenomenon, see Michael J. Barclay et. al., Private Benefits from Block Ownership and Discounts on Closed-End Funds, 33 J. FIN. ECON. 263, 263-64 (1993).

${ }^{37} 413$ A.2d 137 (Del. 1980).

${ }^{38} I d$. at 145 (weighting the asset value of $\$ 456$ per share at $40 \%$ and the capitalized earnings value of $\$ 120$ per share at $60 \%)$.

${ }^{39} I d$. at 141-42 (quoting Tri-Continental, 74 A.2d at 74). Similarly, in Sterling $v$. Mayflower Hotel Corp., 93 A.2d 107, 110 (Del. 1952), the court stated that a dissenting shareholder was entitled to receive "the substantial equivalent in value of the shares he held before the merger," and was not entitled to a share of the firm's liquidating value. 
decision in Tri-Continental for the proposition that the shareholder is to be compensated for her proportionate interest in a going concern. $^{40}$ Once again, the decision was more concerned with the methods for valuing the entire firm than with the proportion to be received by each shareholder. The "proportionate interest" language could fairly be described as dicta. As in Tri-Continental, shareholders who bought into a company, the asset value of which was reduced by agency costs, were not allowed to measure their value upon exit on another basis.

The question of minority discounts, while not directly relevant to our consideration of the value of an entire firm, played a role in the valuation formulation in Cavalier Oil Corp. $v$. Harnett. ${ }^{41}$ That case involved the valuation of a minority shareholder's $1.5 \%$ interest in a closely held corporation where there was no market for the shares. ${ }^{42}$ In an appraisal proceeding, the chancery court valued the entire corporation. On appeal, the majority stockholders argued that Harnett's small interest should have been subjected to a minority discount. The Delaware Supreme Court rejected this argument, citing Tri-Continental and Bell for the "proportionate interest" dicta, and concluded that "to fail to accord to a minority shareholder the full proportionate value of his shares imposes a penalty for lack of control, and unfairly enriches the majority shareholders who may reap a windfall from the appraisal process by cashing out a dissenting shareholder, a clearly undesirable result." ${ }^{\text {"33 }}$ Closely held corporations are not within the set of cases we discuss here, and thus we do not address the logic or wisdom of the holding in Cavalier. We do believe, however, that the result in Cavalier is not compelled by the holdings of the going concern cases for publicly traded shares. The real point is that Cavalier, like earlier decisions, provides no support for the imputation of a control premium in all appraisal cases in order to obtain an "intrinsic value." Nevertheless, the cases we have discussed form the doctrinal basis for the control premium cases that followed.

\footnotetext{
40 Bell, 413 A.2d at 141.

${ }^{41} 564$ A.2d 1137 (Del. 1989).

42 Id. at 1144 .

${ }^{43}$ Id. at 1145 .
} 


\section{The Market Price and Minority Discount Argument}

Delaware began approaching its modern formulation of value in 1985 , in Smith v. Van Gorkom. ${ }^{44}$ In that case, the court held that a board's reliance on the market price of Trans Union's stock was unjustified if the board's task was to determine the intrinsic value of a firm for purposes of judging the adequacy of a sale price. ${ }^{45}$ At issue was a proposed control transaction that reasonably anticipated a premium. $^{46}$ The Delaware Supreme Court stated that " $[t]$ he parties do not dispute that a publicly-traded stock price is solely a measure of the value of a minority position and, thus, market price represents only the value of a single share." ${ }^{\text {"7 }}$ This assumption that the whole is greater than the sum of its parts is the first suggestion of the content of "intrinsic value."

The use of control premiums was not fully developed in Delaware until the 1992 decision of Rapid-American Corp. $v$. Harris. ${ }^{49}$ The subject corporation, Rapid-American Corp. (Rapid) was a diversified holding company with three operating subsidiaries providing virtually all of its income. ${ }^{50}$ The dominant shareholder group, controlled by Meshulam Riklis, had acquired $46.5 \%$ of Rapid's stock over the preceding seven years. $^{51}$ The merger, which took the company private, resulted in the cash-out of holders of approximately $53.5 \%$ of Rapid's stock. ${ }^{52}$ The market price of Rapid's stock, unaffected by the announcement of the merger, was $\$ 17.25$ per share. ${ }^{53}$ The cash-out provided cash and securities valued at approximately $\$ 28$ per share, representing a $62 \%$

4488 A.2d 858 (Del. 1985).

${ }^{45} I d$. at $875-76$.

${ }^{46}$ One of us has argued elsewhere that predicting control premiums in the context of a contemplated control transaction is an impossible exercise, because it involves predicting the outcome of an auction. Carney, supra note 30 , at 532-35.

47488 A. $2 d$ at 876.

${ }^{48}$ The court relied in part on claims by Trans Union managers that its stock was "undervalued," and acknowledged that this was a widely held view of managers. Id. One could also characterize this as a cognitive bias entitled to little or no credence. The valuation question is clouded by Trans Union's possession of tax benefits it could not utilize in its current form, but we fail to see how this differs from the valuable assets trapped in a closed-end fund or the timber holdings of Kirby Lumber, at least in the context of an appraisal proceeding.

49 603 A.2d 796 (Del. 1992).

Id. at 799 .

${ }^{51} I d$. at $799-800$.

${ }^{52}$ Id. at 800 .

${ }^{53}$ Harris v. Rapid-Am. Corp., No. 6462, 1992 Del. Ch. LEXIS 75, at *7 (Del. Ch. Apr. 1, 1992). 
premium. ${ }^{54}$ In the appraisal proceeding, the company's experts valued Rapid as a conglomerate, which it was. The dissenter's expert, on the other hand, disaggregated the company and valued its subsidiaries separately, reasoning that while there were no comparable conglomerates, there were companies comparable to each of the subsidiaries. ${ }^{55}$ Having reached a market value for each of the subsidiaries, the dissenter's expert then added a control premium, because Rapid owned all the stock of each subsidiary. ${ }^{56}$ Citing Tri-Continental as authority for valuation adjustments (from net asset value) at the corporate level, the Delaware Supreme Court approved the addition of a control premium to the extrapolated market value for each subsidiary. ${ }^{57}$ The court noted that the dissenter's expert had valued the subsidiaries by using the market price of similar shares and that " $[t]$ hese shares presumptively traded at a price that discounted the "control premium.", 58 The court concluded that " $\mathrm{t}] \mathrm{h}$ he exclusion of a 'control premium' artificially and unrealistically treated Rapid as a minority shareholder. Contrary to Rapid's arguments, Delaware law compels the inclusion of a control premium under the unique facts of this case. ${ }^{, 59}$

The "unique facts" to which the court referred must have been Rapid's status as a holding company, which operated only through its three wholly-owned subsidiaries. ${ }^{60}$ This approach was followed in M.G. Bancorporation, Inc. v. Le Beau, in which the holding company possessed a majority interest in two operating banks. ${ }^{61}$ In that case, the

${ }^{54}$ Rapid-Am. Corp., 603 A.2d at 798, 800.

${ }^{55} I d$. at 800 . Disaggregating Rapid and valuing its assets separately from the conglomerate as a going concern was an approach previously rejected in both TriContinental Corp. v. Battye, 74 A.2d 71, 76-77 (Del. 1950) and Bell v. Kirby Lumber Corp., 413 A.2d 137, 141 (Del. 1980). It omits the discount from asset values caused by the agency costs that inhere in the conglomerate form. In contrast, Tri-Continental Corp.'s valuation process reflected these agency costs. $74 \mathrm{~A} .2 \mathrm{~d}$ at 77 .

${ }^{56}$ Harris v. Rapid-Am. Corp., No. 6462, 1990 Del. Ch. LEXIS 166, at *18-20 (Del. Ch. Oct. 2, 1990).

${ }^{57}$ Rapid-Am. Corp., 603 A.2d at 805-06.

${ }^{58} I d$. at 806.

${ }^{59} I d$.

${ }^{60}$ In M.G. Bancorporation, Inc. v. Le Beau, 737 A.2d 513 (Del. 1999), the court rejected as too narrow the argument that the "unique fact" in Rapid-American was that its subsidiaries were involved in three separate industries. Id. at 525. "Therefore, any holding company's ownership of a controlling interest in a subsidiary at the time of the merger is an 'operative reality' and an independent element of value that must be taken into account in determining a fair value for the parent company's stock." Id.

${ }^{61}$ Id. 
court sanctioned valuation of subsidiaries based on acquisition prices paid for comparable banks. ${ }^{62}$

This doctrine could have been limited to the valuation of holding companies. $^{63}$ It began modestly in Tri-Continental with the holding that the market value of assets, namely marketable securities, could be adjusted to reflect their diminished value when held by a closed-end investment company. ${ }^{64}$ While the Delaware Supreme Court has recently noted this fact, it has declined to limit adjustments in market values to such cases. ${ }^{65}$ Rather, the Delaware Chancery Court has extended this approach to all corporate valuations, holding that valuation based on analysis of comparable companies "produces an equity valuation that inherently reflects a minority discount.... Because that value is not fully reflective of the intrinsic worth of the corporation on a going concern basis, this court has applied an explicit control premium in calculating the fair value of the equity in an appraisal proceeding." ${ }^{66}$ At this point numerous decisions apply this approach. ${ }^{67}$

Unfortunately this approach misses an important feature of the Tri-Continental decision: In valuing a closed-end investment company,

${ }^{62}$ Id.; see also Hintmann v. Fred Weber, Inc., No. 12839, 1998 Del. Ch. LEXIS 26, *26-31 (Del. Ch. Feb. 17, 1998) (adding a control premium to determine the value of shares in a merger with corporation's holding company).

${ }_{63}$ Most interestingly, with respect to the diversified holding companies structure, any "control premium" based on the holding company's ownership might actually be negative. See James A. Miles \& James D. Rosenfeld, The Effect of Voluntary Spin-off Announcements on Shareholder Wealth, 38 J. FIN. 1597, 1597 (1983) (analyzing the effects of spin-offs and finding that spin-off announcements enhance shareholder wealth); James D. Rosenfeld, Additional Evidence on the Relation Between Divestiture Announcements and Shareholder Wealth, 39 J. FIN. 1437, 1437-38 (1984) (continuing the analysis described in the previous article).

64 Tri-Continental Corp. v. Battye, 74 A.2d 71, $76-77$ (Del. 1950).

${ }^{65}$ Paskill Corp. v. Alcoma Corp., 747 A.2d 549, 556 (Del. 2000) (citing Rapid-Am. Corp. v. Harris, 603 A.2d 796, 806 (Del. 1992)).

${ }_{66}$ Borruso v. Communications Telesystems Int'l., 753 A.2d 451, 458 (Del. Ch. 1999) (citing Kleinwort Benson Ltd. v. Silgan Corp., No. 11107, 1995 Del. Ch. LEXIS 75 , at *6 (Del. Ch. June 15, 1995)).

${ }^{67}$ See, e.g., Bomarko, Inc. v. Int'l Telecharge, Inc., 794 A.2d 1161, 1185-86 (Del. Ch. 1999) (rejecting defendant's contention that a comparable company valuation need not incorporate a control premium); Borruso, 753 A.2d at 458-59 (noting that this approach is "particularly appropriate [when] the comparable company method is the only method available to [value the shares]"); Kleinwort Benson, 1995 Del. Ch. LEXIS 75 , at *6-7 (stating that the expert's comparison study needed to be adjusted to compensate for the minority discount); Salomon Bros. v. Interstate Bakeries Corp., No. 10054, 1992 Del. Ch. LEXIS 100, at*16-17 (Del. Ch. May 1, 1992) (recognizing that premium value is often used in acquisitions). 
the court in Tri-Continental valued the assets as they existed in a going concern-that is, at a discount from each asset's independent fair market value. This discount, which some say exists because of the agency costs of closed-end firms, ${ }^{68}$ would persist until the firm was liquidated or acquired by some other type of firm with lower agency costs. At the same time, if control blocks in closed-end firms enable owners to extract private benefits at the expense of the public shareholders, these blocks should trade at a premium. ${ }^{69}$ In short, it is important to note that the court did not calculate firm value as if a change of control were about to occur. Rather, it assumed the continuing management of the business as it then existed-with no valuecreating control transaction.

The current approach leads Delaware courts to speculate about takeover values under circumstances where the probability of a takeover may be quite remote, as it was in Rapid-American. This approach also leads courts into the risky exercise of predicting control premiums if companies were sold, which are precisely the "speculative elements of value [that] should be excluded from the valuation calculus." 70

\section{The Control PREMIUM Literature}

We introduce this topic with a qualification and an explanation. Our arguments only apply to those companies with stock traded in what are commonly understood to be efficient capital markets, where stock prices are set in an unbiased (competitive) manner and reflect all publicly available information. The basic conclusion of the Efficient Capital Markets Hypothesis (ECMH) is that market values of companies' shares traded in competitive and open markets are

${ }^{68}$ See Barclay et al., supra note 36, at 282 (stating that "[o] thers have tried to explain discounts by focusing on the traditional agency conflict between owners and managers").

${ }^{69}$ See id. at 268, 276-81 (demonstrating that the presence of large block holdings increases the discounts from net asset value in closed-end funds from four percent to fourteen percent, and examining the ways in which blockholders extract benefits not shared with public stockholders). Were these large blocks to be transferred, we assume that these benefits would be priced, thus creating a premium over market prices.

${ }^{70}$ Gonsalves v. Straight Arrow Publ'rs, Inc., 701 A.2d 357, 362 (Del. 1997); see also Cede \& Co. v. Technicolor, Inc., 684 A.2d 289, 295 (Del. 1996) (explaining that the "future values" allowed in a value calculation under Weinberger do not include those elements of future value that "but for the merger ... would not exist"); Weinberger $v$. UOP, Inc., 457 A.2d 701, 713 (Del. 1983) ("[E]lements of future value ... which are known or susceptible of proof as of the date of the merger and not the product of speculation may be considered."). 
unbiased estimates of the value of the equity of such firms. ${ }^{71}$ We do not claim that any market is perfectly efficient; that is not a necessary condition of our argument. Rather, we claim that a presumption should be employed that market prices are efficiently set and reasonably accurate ${ }^{72}$ absent convincing evidence to the contrary. Given the courts' institutional difficulties in making alternative estimates of value, it is only prudent to minimize the adversarial process, in which two experts take polar positions, by giving deference to market values. $^{73}$ For those with greater skepticism about ECMH, in Part III we offer an alternative argument about fairness and in Part IV we demonstrate the conflicts created by the control premium decisions.

We do not address appraisal valuations in second-stage takeout mergers that follow a successful takeover bid. ${ }^{74}$ We also do not deal with closely-held corporations and the related problems of minority and liquidity discounts, where there is no ascertainable market price. ${ }^{75}$

${ }^{71}$ Without engaging in a full discussion of ECMH, this is generally what is referred to as semi-strong form efficiency. We do not digress to discuss recent challenges to ECMH, except to note that ECMH remains, in the view of some, one of the bestestablished hypotheses in all the social sciences. See, e.g., Jensen, supra note 21 , at 11 (noting that " $[a]$ lthough the evidence is not literally 100 percent in support of the efficient market hypothesis, there is no better documented proposition in any of the social sciences"); see also Ronald J. Gilson \& Reinier H. Kraakman, The Mechanisms of Market Efficiency, 70 VA. L. REV. 549, 550 (1984) ("ECMH is now the context in which serious discussion of the regulation of financial markets takes place"); Ok-Rial-Song, Hidden Social Costs of Open Market Share Repurchases, 27 J. CORP. L. 425, 452 (2002) (stating that empirical studies have left no doubt that ECMH is still a "fundamental paradigm [] for analyzing modern capital markets in current studies of corporate law and financial economics" (footnotes omitted)). Close corporations present a different set of problems, which depend in part on how one views the absence of contractual protection for minority shareholders as affecting the value of their shares.

${ }^{72}$ See Applebaum v. Avaya, Inc., 812 A.2d 880, 890 (Del. 2002) ("[A] wellinformed, liquid trading market will provide a measure of fair value superior to any estimate the court could impose.").

${ }^{73}$ For an illustration of the difficulties with valuation in the adversarial context, see Cede \& Co. v. Technicolor, Inc., No. 7129, 1990 Del. Ch. LEXIS 259, at*4-5 (Del. Ch. Oct. 19, 1990), where rival appraisers valued the stock at $\$ 62.75$ and $\$ 13.14$, which Chancellor Allen attributed to the "dynamics of litigation." Chancellor Allen thought that the problem was so great that he discussed the merits of simply selecting the valuation of one of the two appraisers-noting the power such a decision would have in persuading experts to employ more reasonable assumptions. Id. at *27 n.17.

${ }^{74}$ While the Rapid-American merger involved a $47.9 \%$ shareholder, that block was accumulated over seven years through a combination of purchases by the shareholder and repurchases by Rapid-American. Harris v. Rapid-Am. Corp., No. 6462, 1990 Del. Ch. LEXIS 166, at *2-3 (Del. Ch. Oct. 2, 1990).

${ }^{75}$ The problem of disparity of treatment in close corporations is more complex. Shareholders have the ability to protect themselves against freeze-outs by contract, but apparently a significant number fail to do so. F. Hodge O'Neal, Close Corporations: 
Finally, we do not focus on the question of whether market prices may be depressed because the controlling shareholder has extracted excessive (and presumably illegal) private benefits from the corporation. $^{76}$

\section{A. Common Sense About Control Premiums}

The received economic wisdom of courts may contain some fundamental misconceptions about value. The misunderstanding involved is understandable, in part, because control premiums are observable. It also has a certain intuitive quality that seems to confirm its truthfulness. Whenever control of a company is transferred, one can easily observe that the transfer occurs at a price above the preannouncement market value of the shares.

A rich empirical literature demonstrates that these premiums exist, and that they can be large. For instance, Michael Jensen estimated shareholder gains from mergers and acquisitions at $\$ 40$ billion between 1981 and $1985 .{ }^{77}$ Joseph Grundfest and Bernard Black found total shareholder gains of $\$ 167$ billion between 1981 and $1986 .^{78} \mathrm{~A}$ third study found premiums of $\$ 118.4$ billion in the same period. ${ }^{79}$ From this, it is easy to see how one could conclude that such premiums inhere in all companies and should be considered in any particular company's appraisal. The intuitive appeal stems from the desire to protect minorities from overreaching by majorities, and the apparent belief that whenever any minority shareholder receives something

Existing Legislation and Recommended Reform, 33 BUS. LAw. 873, 881 (1978) (attributing this failure to the fact that many minority shareholders do not anticipate dissension or oppression, and are not aware of their own vulnerabilities). Whether fairness requires minority shareholders to live with the consequences of their inaction, or requires imposition of a burden on controlling shareholders to bargain ex-ante, is a question that complicates this issue. For a discussion of placing burdens on parties who are most aware of contract choices, see Ian Ayres \& Robert Gertner, Filling Gaps in Incomplete Contracts: An Economic Theory of Default Rules, 99 YALE L.J. 87, $101-07$ (1989).

${ }^{76}$ Where the price is so depressed, we presume that a derivative action would be available against the controlling shareholder and that the expected value of that recovery is an element of going concern value to be added to market value.

77 Jensen, supra note 21 , at 7.

78 News Release, Joseph Grundfest \& Bernard Black, Securities and Exchange Commission, Stock Market Profits from Takeover Activity Between 1981 and 1986: $\$ 167$ Billion is a Lot of Money (Sept. 28, 1987) (on file with author).

${ }^{79}$ Gregg A. Jarrell et al., The Market for Corporate Control: The Empirical Evidence Since 1980, J. ECON. PERSPS., Winter 1988, at 49, 49; see also Hamermesh, supra note 17, at 886, 913 App. A tbl.1 (offering further evidence of large control premiums). 
different in kind (e.g., shares rather than cash), there has been some element of overreaching or unfairness.

Our reason for suggesting that this conclusion is a misunderstanding is relatively simple: control premiums only occur in transactions involving a transfer of control, where there are thought to be gains from trade, either because of a perception by the purchaser that the transaction offers some opportunity to create new value within the target firm $^{80}$ or because the bidder believes that the market value of the target's shares is depressed and it can earn an abnormal return by holding target shares until the market price reflects full value. ${ }^{81}$ Even if all values, both present and potential, are valued in the market price for the firm's shares, one would not expect to find a discernible control premium in a widely held firm that is well managed and appears to offer little probability of a transfer of control. Any small probability of a control transaction will already be reflected in the market price, because absent a dominant shareholder, all shareholders expect to have an equal opportunity to share in any such premium, should it appear. Absent an actual transfer of control, control premiums represent probabilities of a control transfer at a premium. Where the probability is close to zero, so is the premium.

\section{B. Stories of Separate Markets}

We turn now to the academic discussion of the market for corporate control and the arguments concerning control premiums that

${ }^{80}$ These premiums are offered in public tender offers in order to overcome freerider problems. See Sanford J. Grossman \& Oliver D. Hart, Takeover Bids, the Free-Rider Problem, and the Theory of the Corporation, 11 BELL J. ECON. 42, 42-43 (1980) (noting that shareholders can free ride on a bidder's improvement of a poorly run corporation after a successful takeover bid, thereby limiting the raider's profit and making the takeover less likely to occur). In the case of a negotiated purchase of control from a single shareholder or a group, the premium is offered both to account for the private benefits controlling shareholders receive and to provide a price that at least meets their reservation price, but may well be higher because of the uncertainties of negotiating under conditions of bilateral monopoly. For example, in Cooper v. Pabst Brewing Co., Vice Chancellor Hartnett rejected the blended value of a takeover bid as the measure of the target's value on the date of the merger, stating that it "is often an unreliable guide to the true market value because it may reflect a control premium and other factors connected with the acquiror's [sic] intentions but unrelated to the value of the firm as a going concern." No. 7244, 1993 Del. Ch. LEXIS 91, at *22 (Del. Ch. June 8, 1993).

ECMH suggests that some of these bidders are correct and some are not, but that there is no way to determine this except to wait to see what actually happens to the market price. The evidence to date is not encouraging for bidders. See, e.g., Black, supra note 17 (exploring several possible explanations for bidder overpayments). 
have flowed from it. As explained above, we argue that control premiums are reflected in all stock prices. ${ }^{82}$

The phrase "market for corporate control" was introduced in 1965 by Henry Manne's classic article, Mergers and the Market for Corporate Control. $^{83}$ Manne introduced the concept of a market for corporate control without claiming that it was somehow separate from the market for small lots of shares. He simply argued that, as management quality and effort declined, so did expected earnings, so that stock prices would decline relative to those of well-managed companies. A lower stock price would both facilitate and provide the impetus for takeovers, costly as they might be. He observed that "the potential return from the successful take-over and revitalization of a poorly run company can be enormous." ${ }^{84}$ While other explanations of gains have since been offered, Manne's explanation remains a central one. It integrates control transactions with trading transactions in an important way. For instance, a takeover bid introduces important new information about the value of a firm-that someone, other than current management, believes they could achieve greater cash flows for investors from the existing assets. ${ }^{85}$ In the parlance of efficient market analysis, this is "news." The fact that a takeover bid is a low-probability event for many firms explains why prices of even badly managed firms do not rise to reflect the full value of a potential control premium; they reflect only its expected value under conditions of uncertainty. ${ }^{86}$ Many firms are well managed, or at least not much more badly managed then the average, and consequently offer few potential gains in a takeover. In such a case, both the probability of and expected gains from a takeover bid may be trivial. But in both cases, efficient markets should set prices to reflect the particular situation of each firm.

Not all scholars accept this view. One counterexplanation has been offered by Martin Shubik: "These assumptions [of efficient capital markets] ... are set up to rule out, by assumption, the possibility

${ }^{82}$ Supra Part II.A.

${ }^{83}$ Henry G. Manne, Mergers and the Market for Corporate Control, 73 J. POL. ECON. 110,112 (1965). For a review of the impact of this and other articles by Manne regarding takeover premiums, see William J. Carney, The Legacy of "The Market for Corporate Control" and the Origins of the Theory of the Firm, 50 CASE W. RES. L. REV. 215 (1999).

${ }^{84}$ Manne, supra note 83, at 113.

${ }^{85}$ The market price of the target's stock reflects the anticipated takeover bid in advance of its announcement. See Michael Bradley, Interfirm Tender Offers and the Market for Corporate Control, 53 J. Bus. 345, 361-65 (1980) (illustrating the predicted time series of the share prices of target firms involved in successful tender offers).

${ }^{86}$ Id. 
that the market for a few shares of the stock of a corporation and the market for control of a corporation may be fundamentally different markets." ${ }^{87}$ Shubik elaborates on his challenge to the law of one price:

The lawyers may talk about a premium for control. But to a true believer of efficient markets, there cannot be a premium for control. If, in contradistinction to the adherents of the single, efficient market, we suggest that there are several more or less imperfect markets involving the market for a few shares, the market for control, the market for going-business assets, and the market for assets in liquidation, then we have a structure for interpreting what is going on in terms of arbitrage among these different markets.

Shubik's argument uses the term "market" loosely. Stigler has described a "market" as a situation where prices of homogeneous goods are identical. ${ }^{89}$ Discrete markets exist when different prices appear, which are generally not arbitraged away because of transaction costs, transportation costs, or cultural differences that inhibit complete arbitrage. ${ }^{90}$ Significantly different prices are not observed for the same stock at the same time, except perhaps in the irrelevant

${ }^{87}$ Martin Shubik, Corporate Control, Efficient Markets, and the Public Good, in KNIGHTS, RAIDERS, AND TARgETS: THE IMPACT OF THE HOSTILE TAKEOVER 31, 32-33 (John C. Coffee, Jr. et al. eds., 1988).

${ }^{88}$ Id. at 33; see also Lynn A. Stout, Are Takeover Premiums Really Premiums? Market Price, Fair Value, and Corporate Law, 99 YALE L.J. 1235, 1264-75 (1990) (arguing that control premiums are generated by a downward-sloping demand curve). Shubik's language was quoted by Chancellor Allen in Paramount Communications, Inc. v. Time, Inc., Nos. 10866, 10670, 10935, 1989 Del. Ch. LEXIS 77, at *55. n.13 (Del. Ch. July 17, 1989). We believe Shubik is mistaken when he claims that true believers in efficient capital markets hold that there cannot be a control premium. See generally Manne, supra note 83. Shubik argues that, when hostile takeovers occur, conditions approximating zero transaction costs in perfectly competitive markets no longer exist. Shubik, supra note 87 , at $35-36$. While he is correct, this point only goes to the probability and size of a control premium. The fact that not all bad managers are removed by takeovers because of these costs does not necessarily mean there are separate markets.

${ }^{89}$ GeORge J. STIGler, The Theory OF Price 85 (3d ed. 1966); see also Joseph Stiglitz, Information, in THE FORTUNE ENCYLOPEDIA OF ECONOMICS 16 (David R. Henderson ed., 1993) ("Under this law, there is a uniform price in the market, and price differences are quickly eliminated by arbitrage."), http://www.econlib.org/ library/Enc/Information.html.

${ }^{9}$ Stiglitz, supra note 89 . Shubik correctly argues that the pool of purchasers of a firm's assets may be different (thinner) than the pool of purchasers of its shares. Shubik, supra note 87 , at 32-33. In some cases, if there is only one prospective asset purchaser, conditions of bilateral monopoly exist, making prediction of the magnitude of a control premium more difficult. But this does not address the probability that a transaction in control will be reflected in the market price. 
sense of different reservation prices. ${ }^{91}$ A takeover bid appears in the same market in which trading occurs, and the news of the bid instantaneously moves the market price to a new level, approximating traders' estimations of the bid's prospect for success, discounting for the time value of money and the probability of oversubscription and prorationing. Thus, there is no evidence of the simultaneous existence of separate market prices for control and for minority interests. This demonstrates that the law of one price prevails at any one time, and that prices change only when the probability of an event, such as a change of control, changes. ${ }^{92}$

Another version of the separate market story is offered without any attempt at a theory: It simply asserts that all publicly traded shares reflect an implicit minority discount. ${ }^{93}$ Responding to an assertion without a theory is impossible and probably not worthwhile. Yet, unfortunately, it is the current operative assumption of the Delaware courts.

While economists have developed sophisticated models demonstrating how arbitrage occurs between markets, ${ }^{94}$ none of these models are necessary in this context, because only one market exists for the shares of each company.

${ }^{91}$ In that sense, investors are price-takers, not price-searchers. Auctions exist to deal with the problems of heterogeneous goods or traders, by allowing efficient pricesearching "where sellers are unsure about the values that bidders attach to the object being sold." VIJAY KRISHNA, AUCTION THEORY 3 (2002). The New York Stock Exchange (NYSE) is a "continuous auction market" that searches for prices intertemporally, as "news" continuously alters reservation prices of both buyers and sellers. See Mark Borelli, Market Making in the Electronic Age, 32 LoY. U. CHI. L.J. 815, 822 (2001) ("The NYSE is a continuous auction market in which orders can be executed anytime the exchange is open.").

92 Coates provides an expanded description of arbitrage under these conditions, pointing out that the presence of a controlling shareholder in the target means that market prices will also reflect the risk that a bidder will acquire control directly from the controlling shareholder and the probability that the new controlling shareholder will deal more or less fairly with the minority shareholders. John C. Coates IV, "Fair Value" as an Avoidable Rule of Corporate Law: Minority Discounts in Conflict. Transactions, 147 U. PA. L. REV. 1251, 1265 n.46 (1999) (citing Lucian Arye Bebchuk, Efficient and Inefficient Sales of Corporate Control, 109 Q.J. ECON. 957, 961-64 (1994)).

93 ShanNon P. Pratt ET al., VAluing a BuSINESS: THE ANalysis and APPRAISAL of Closely Held COMPANIES 304-05 (3d ed. 1996); see also Coates, supra note 92, at $1265 \&$ n. 46.

${ }_{94}$ See, e.g., Kenneth J. Arrow \& Gerard Debreu, Existence of an Equilibrium for a Competitive Economy, 22 ECONOMETRICA 265 (1954) (setting out a competitive economy equilibrium theory). 


\section{Assertions of Demand Elasticities}

Another argument that markets provide unreliable information about firm values is primarily authored by Lynn Stout, who argues that shares of particular corporations are unique and thus scarce assets with downward-sloping demand curves. ${ }^{95}$ This theory also implies an upward-sloping supply curve in the face of a takeover bid. ${ }^{96}$ Under this theory, the market price of shares is an unreliable indicator of value, because unless one knows the slope of the demand curve, one cannot calculate the subjective gains of those valuing their shares at less than the takeover price and the subjective losses of those who value their shares at a higher price. Stout's views seem to be in accord with those of many courts that decline to be guided by market values in an appraisal process. ${ }^{97}$ The principal difficulty with this argument is the assumption that a bidder will ever pay the reservation price of those shareholders whose reservation prices are above the market price. $^{98}$

This theory also directly contradicts modern portfolio theory, which teaches that any investor can build a diversified portfolio by using a variety of financial instruments (minimizing nonsystematic risk) to achieve the desired level of risk and return (accounting for systematic risk). ${ }^{99}$ Hence, the aphorism, "seen one stock, seen them all."100 According to modern portfolio theory, the demand curve for any stock facing a particular selling shareholder is flat (varying reservation

${ }^{95}$ Stout, supra note 88, at 1239; see also Chicago Corp. v. Munds, 172 A. 452, 454-55 (Del. Ch. 1934) ("The relation of supply to demand on a given day as truly affects the market value of a stock as it does of a commodity; and temporary supply and demand are in turn affected by numerous circumstances which are wholly disconnected from considerations having to do with the stock's inherent worth.").

${ }^{96}$ See Stout, supra note 88, at 1267 ("Less-than-unanimous shareholder approval of merger and asset sales ... forces dissenting shareholders to part with their shares for a price they believe inadequate.").

${ }^{97}$ See, e.g., M.P.M. Enterprises v. Gilbert, 731 A.2d 790, 797 (Del. 1999) (“[T]he fairness of the price on the open market is not the overriding consideration."); Harris v. Rapid-Am. Corp., No. 6462, 1992 Del. Ch. LEXIS 75, at *7 (Del. Ch. Apr. 1, 1992). Since Weinberger v. UOP, Inc., 457 A.2d 701, 712 (Del. 1983), market value has been just one of many factors used to determine value.

${ }^{98}$ There are other serious difficulties with Stout's arguments. See J. Gregory Sidak \& Susan E. Woodward, Takeover Premiums, Appraisal Rights and the Price Elasticity of a Firm's Publicly Traded Stock, 25 GA. L. REV. 783, 785-86 (1991) ("Stout's claim of lessthan-infinite price elasticity does not advance her thesis that the market price of a security is an unreliable and unfair measure of value.").

${ }_{99}$ BREALEY \& MYERS, supra note 3, at 191-201.

${ }^{100}$ Id. at 375 . 
prices among some prospective buyers notwithstanding), ${ }^{101}$ and the supply curve facing any buyer (not signaling a prospective takeover bid or possession of material nonpublic information) is equally flat. In short, absent a takeover bid, no shareholder can obtain more than the present market price for her shares when selling them. We are all price-takers, absent a takeover bid.

\section{Coordination Costs: Private Benefits of Complete Ownership}

To the extent that shareholders are heterogeneous and dispersed, conflicts may arise among them over divergent preferences for firm distributions, investments, and risky projects. ${ }^{102}$ If controlling shareholders can resolve these conflicts in their favor, then value would be added to their shares at the expense of the minority's shares, with little risk of being held liable for wrongdoing. ${ }^{103}$ Controlling shareholders may also receive some private benefits by reallocating firm resources to directly benefit themselves, thereby taking value from minority shareholders. Several studies have found that large blocks persistently trade at premiums-absent any attempt to engage in a takeover-suggesting that markets may price these private benefits. ${ }^{104}$

While the potential for the benefits through misallocation of firm resources is undeniable, the probability that these activities are significant enough to account for the magnitude of control premiums in a

101 For an argument that demand curves slope downward, based on observed price increases upon the announcement of the inclusion of a stock in the Standard \& Poor's 500 Index, see Andrei Shleifer, Do Demand Curves for Stocks Slope Down?, 41 J. FIN. 579 (1986). The most probable explanation, according to Shleifer, is that an outward shift in the demand curve occurs because index funds must now purchase the stock, and the increased demand pushes the demand curve outward and places the new equilibrium further out on what is implicitly an upward-sloping demand curve. Id. at 580 . While this suggests that increasing demand from groups of investors such as index funds may affect price (without any information signal), it does not challenge the essential flatness of the curves facing individual investors. Indeed, it is impossible to differentiate between moves along one curve or the other (with either or both having a slight slope) and a shift in that curve.

${ }^{102}$ William J. Carney, The Theory of the Firm: Investor Coordination Costs, Control Premiums and Capital Structure, 65 WASH. U. L.Q. 1, 5 (1987). Generally these problems are solved either by the constituency effect, in which shareholders invest in firms with announced policies they prefer, or by diversification.

${ }^{103}$ See Sinclair Oil Corp. v. Levien, 280 A.2d 717, 720 (Del. 1971) (sustaining a dividend increase over minority shareholders' objections).

${ }^{104}$ See, e.g., Michael J. Barclay \& Clifford G. Holderness, Private Benefits from Control of Public Comporations, 25 J. FIN. ECON. 371 (1989) (finding that large blocks trade at a twenty percent premium over market); see also Barclay et al., supra note 36 , at 275-81 (detailing some of the private benefits received from control of closed-end funds). 
significant number of cases is likely negligible because of the stringent legal rules against such activity. ${ }^{105}$ On the other hand, the minimization of coordination costs and the ability to decide among distribution and investment opportunities are benefits that can never flow to shareholders generally. Instead, most shareholders must select companies that have credibly signaled policies that correspond to their own preferences. To the extent that other private benefits are similar to agency costs, they too cannot be shared with public investors. Either a controlling shareholder captures them or management itself captures them (although they are called agency costs). In competitive markets these costs are irreducible, because the marginal costs of further monitoring and prevention devices exceed marginal gains. ${ }^{106}$

\section{THE FAIRNESS ARGUMENTS}

In Part II, we argued that in the absence of an imminent and readily valued control transaction, receipt of the market price by minority shareholders in effect gives them their pro rata share of the value of the firm. In this Part, we relax the assumption that shares are traded in efficient capital markets that formed the basis for the discussion in Part II. Indeed, for present purposes, whether market prices fully reflect all publicly available information and result in prices being set in an unbiased manner is largely irrelevant. All we assume in this Part is that investors know when a controlling shareholder dominates corporate policy, along with whatever probabilities that creates for a freezeout transaction or some disproportionate distribution of the benefits that flow from stock ownership. Lacking other legal guidance, we define "unfairness" here as a failure to receive bargained-for property

${ }^{105}$ See, e.g., Sinclair Oil Corp., 280 A.2d at 722-23 (holding a parent corporation liable for failure to pay a subsidiary promptly and take all product required under an output contract); see also Roger C. Graham, Jr. \& Craig E. Lefanowicz, Majority and Minority Ownership of Publicly-Traded Firms: A Test of the Value of Control Using Market Multiples, 26 J. BUS. FIN. \& ACCT. 171, 183-92 (1999) (presenting evidence that expropriation benefits are not included in the valuation of target companies). But see Barclay et al., supra note 36 , at 285 (arguing that the discount from net asset value reflected in the market value of shares of closed-end funds reflects, inter alia, the ability of large block holders to divert profits to themselves).

${ }^{106}$ See generally Michael C. Jensen \& William H. Meckling, Theory of the Firm: Managerial Behavior, Agency Costs and Ownership Structure, 3 J. FIN. ECON. 305 (1976). 
rights. ${ }^{107}$ What follows is a discussion of what public investors really own.

\section{A. What Property Rights Are Relinquished by a Dissenting Shareholder?}

\section{Public Shareholders' Expectations of Control of Their Firm}

The Delaware courts have stated that in appraisal proceedings the courts are to assume that the dissenting shareholder would have preferred to remain a shareholder in the original enterprise. This underlies the statement in Tri-Continental that "the stockholder is entitled to be paid for that which has been taken from him, viz., his proportionate interest in a going concern." 108 Thus, in M.G. Bancorporation v. Le $B e a u,{ }^{109}$ the Delaware Chancery Court rejected an appraisal based on market values, because the witness "had determined only the "fair market value' of MGB's minority shares, as opposed to valuing MGB in its entirety as a going concern and then determining the fair value of the minority shares as a pro rata percentage of that value."110 The Delaware courts have thus moved from a presumption that a public shareholder only owns a minority interest (in sale of control cases) to a claim of entitlement to a pro rata share of firm value. Implicitly, this gives the investor a right to a pro rata share of all the benefits flowing from the corporation to its owners. ${ }^{11}$

${ }^{107}$ See Benjamin Hermalin \& Alan Schwartz, Buyouts in Large Companies, $25 \mathrm{~J}$. LEGAL STUD. 351, 361-62 (1996) ("Property theory ... implies that a minority shareholder's rights derive only from the corporate contract.").

${ }^{108}$ Tri-Continental Corp. v. Battye, 74 A.2d 71, 72 (Del. 1950). The court stated that "fair value" must be equal to what the shareholder "would have received . . in one way or another as long as the company continued in business." Id. at 76. Ironically, the court also stated that the only way for a shareholder to receive value is "by the sale of [his or her stock] on the market," which would be at a discount if one assumes that discounts generally exist. Id.

${ }^{109}$ M.G. Bancorporation, Inc. v. Le Beau, 737 A.2d 513 (Del. 1999)

${ }^{110} I d$. at 518 (citing Nebel v. Southwest Bancorp, No. 13618, 1995 WL 405750, at *4 (Del. Ch. July 5, 1995)).

111 The Delaware Supreme Court has noted:

The underlying assumption in an appraisal valuation is that the dissenting shareholders would be willing to maintain their investment position had the merger not occurred. Accordingly, the Court of Chancery's task in an appraisal proceeding is to value what has been taken from the shareholder, i.e., the proportionate interest in the going concern. To that end, this Court has held that the corporation must be valued as an operating entity. We conclude that the Court of Chancery did not adhere to this principle.

Cede \& Co. v. Technicolor, Inc., 684 A.2d 289, 298 (Del. 1996) (citations omitted). 
In addition to being an unrealistic reflection of the value to be received on a sale of control, it does not reflect the reality of day-today operations. A majority shareholder has exclusive control over dividend policy, investment policy, and the timing of the sale or liquidation of the firm. Any or all of these factors may-given different situations about taxes, alternative investment opportunities, and the like-impact different shareholders differently. ${ }^{112}$ Despite the criticism of an older line of commentary, ${ }^{113}$ the control premium does not appear to be explained generally by the ability to loot the firm or engage in any wrongdoing and potential expropriation benefits appear to be too small to influence the valuation of target companies. ${ }^{114}$

This position also ignores the agency cost literature of the last sixty years that has demonstrated the lack of control by public shareholders. ${ }^{115}$ The only solution to the agency cost problem, it is said, is the acquisition of a large (control) block that allows the holder to capture enough of the benefits of monitoring to compensate for the loss

${ }^{112}$ See, e.g., Sinclair Oil Corp. v. Levien, 280 A.2d 717, 721 (Del. 1971) (presenting a minority shareholder's objection to "excessive" dividend payments). One suspects that individuals facing top marginal income tax rates as high as ninety percent might have felt differently about the benefits of dividends than a corporate majority shareholder that could benefit from a one hundred percent dividends received deduction under I.R.C. \$ 243 (1986). See generally Carney, supra note 102.

${ }^{113}$ See, e.g., William D. Andrews, The Stockholder's Right to Equal Opportunity in the Sale of Shares, 78 HARV. L. REV. 505, 509 (1965) (discussing the so-called "looting cases" where a "purchaser buys a controlling block of stock at a premium over value, ... [and] utilizes his new place of power to steal from the corporation"); Eugene V. Rostow, To Whom and for What Ends is Corporate Management Responsible?, in THE CORPORATION IN MODERN SOCIETY 46, 47 (Edward S. Mason ed., 1959) (observing the widely held view that "the act of [corporate] raiding breaches a standard of business propriety with an even stronger claim to the loyalty of respectable opinion"). Manne, supra note 83 , at $112-13$, rejects this argument on the basis that control premiums have been too large to be justified by undetected looting.

${ }^{114}$ See Graham \& Lefanowicz, supra note 105, at 175 (noting "that majority ownership does not necessarily result in direct asset expropriation from minority shareholders").

${ }^{115}$ See e.g., Adolf A. Berle, Jr. \& Gardiner C. Means, The Modern CorpoRATION AND PRIVATE PROPERTY 84 (1932) (asserting that a corporation's management will be largely indifferent to the concerns of shareholders when "ownership is so widely distributed that no individual or small group has even a minority interest large enough to dominate the affairs of the company"); Harold Demsetz \& Kenneth Lehn, The Structure of Corporate Ownership: Causes and Consequences, 93 J. POL. ECON. 1155, 1174 (1985) ("The higher cost and reduced profit that would be associated with this loosening in owner control should be offset by lower capital acquisition cost or other profitenhancing aspects of diffuse ownership ...."); Jensen \& Meckling, supra note 106, at 308 (defining agency costs as the sum of "(1) the monitoring expenditures by the principal, (2) the bonding expenditures by the agent, [and] (3) the residual loss" (footnote omitted)). 
of diversification. ${ }^{116}$ No one claims that public shareholders have the ability to create value by reducing these costs.

Finally, this position of entitlement to remain a shareholder in a going concern ignores the property rights of minority shareholders. Minority shareholders do not have a right to remain shareholders -however willing they may be-in the face of majority voting rules on such questions as asset sales, liquidations, mergers and reverse stock splits. ${ }^{177}$ All of these events may cause the involuntary exit of minority shareholders. In contrast to some other jurisdictions, only mergers create dissenter's rights in Delaware. ${ }^{118}$ In all other cases, absent fraud or equitable grounds for judicial interference, shareholders must take what the transaction produces for them.

\section{Public Shareholders' Expectations of a Control Premium}

The sale of a control block of shares illuminates the law's general policy in control transactions. Is it unfair for a controlling shareholder to secure the entire control premium for itself by selling all its shares? The judicial answer has almost universally been no. ${ }^{119}$ Where

${ }^{116}$ See Carney, supra note 102, at 12 ("The dominant stockholder, in a publicly held firm, who is able to determine the outcome of firm decisions, is not subject to the risks of losing arguments about firm policy."); Frank H. Easterbrook \& Daniel R. Fischel, Corporate Control Transactions, 91 YALE L.J. 698, 705 (1982) ("The sale of a control bloc of stock ... allows the buyer to install his own management team, producing the same gains available from a tender offer for a majority of shares but at lower cost to the buyer."); $c f$. Jeffrey N. Gordon \& Lewis A. Kornhauser, Efficient Markets, Costly Information, and Securities Research, 60 N.Y.U. L. REV. 761, 830-33 (1985) (positing that because "markets are at best 'relatively' efficient" it will be lucrative for potential investors to avoid diversification and instead search for undervalued securities).

117 See, e.g., In re Resorts Int'l, Inc. S'holders Litig. Appeals, 570 A.2d 259, 268 (Del. 1990) ("This Court long ago rejected the concept that a shareholder has an absolute right to remain a shareholder in the face of an otherwise legislatively recognized procedure for effecting a cash-out merger."); Federal United Corp. v. Havender, 11 A.2d 331, 338 (Del. 1940) (noting that "the average intelligent mind must be held to know" that the rights of preferred shareholders to dividend arrearages might be altered if the issuing corporation merges with another corporation).

${ }^{118}$ Compare Del. Code ANN. tit. 8, \$ 262(b) (2001), with N.J. STAT. ANN. \$ 14A:11-1 (West 1993) (allowing dissenter's rights upon merger, sale, lease, or exchange of assets), and N.Y. BUS. CORP. LAW $\$ 910$ (McKinney 1993) (permitting dissenter's rights upon merger, sale, lease, exchange of assets, or share exchange).

${ }^{119}$ The overwhelming body of judicial authority holds that a controlling shareholder is entitled to extract a control premium when selling shares. See Robert W. Hamilton, Private Sale of Control Transactions: Where We Stand Today, 36 CASE W. RES. L. REV. 248, 249 (1985) ("It is unlikely that any American court today would reject the general proposition that controlling shareholders may obtain a premium for their shares which they need not share with other shareholders."). There are exceptions, such as seizure of corporate opportunities and sales to looters, which are not relevant 
a controlling shareholder exists at the time of purchase, investors can determine that the controlling shareholder may be the exclusive recipient of a control premium and that investment and distribution policies likely will be set by the controlling shareholder. Rational investors in efficient markets, aware of this possibility, will take those features into account when setting the market price for the shares. ${ }^{120}$ Thus, when minority shareholders are cashed out without receiving a control premium, they have received exactly what they bargained for. Further, the amount they receive, if no more than the pre-freeze-out market value, will allow them to purchase a comparable financial asset.

Most shareholders in public corporations, other than founders and their heirs, have purchased their shares in the initial public offering or in public markets after the firm has gone public. Under these circumstances, if some of the arguments set out above are to be believed, founders may be said to have sold their shares at a "minority discount." Any public shareholder contemplating a subsequent sale of these shares will expect that the same discount will apply when she sells. The rule of markets thus facing any public shareholder is "in

here. While Delaware has not faced this question directly, there has been no deviation from the majority rule. In Krieger $v$. Anderson, 182 A.2d 907 (Del. 1962), the Delaware Supreme Court affirmed a dismissal of a complaint by mutual fund shareholders against owners of the former management company for a share of an alleged control premium obtained. Rejecting the argument that several of the stockholders of the management company were directors of the fund and thus owed their gains to the fund, the court criticized the plaintiff's argument, which, taken to its logical conclusion, would mean that management company shareholders "can never sell the shares for what they are really worth." Id. at 910 . In the court's estimation, "[ $\mathrm{t}]$ his conclusion offends one's sense of fairness." Id. In Harris v. Carter, 582 A.2d 222, 224 (Del. Ch. 1990), plaintiffs argued that controlling shareholders had sold their control to a looter. In dicta, Chancellor Allen stated:

While Delaware law has not addressed this specific question, one is not left without guidance from our decided cases. Several principles deducible from that law are pertinent. First, is the principle that a shareholder has a right to sell his or her stock and in the ordinary case owes no duty in that connection to other shareholders when acting in good faith.

Id. at 234 (citing Frantz Mfg. Co. v. EAC Indus., 501 A.2d 401, 408 (Del. 1985)).

${ }^{120}$ See John P. Bransfield, Proposal to Change the Federal Income Taxation of Marketable Securities, 2 Hous. Bus. \& TAX L.J. 328, 373-74 (2002) (noting that "[n]o buyer would pay that amount for a minority position because the buyer would not be in control of operations of the corporation"); Douglas K. Moll, Reasonable Expectations v. Implied-inFact Contracts: Is the Shareholder Oppression Doctrine Needed?, 42 B.C. L. REV. 989, 1060 n.275 (2001) (explaining that a minority shareholder will sometimes sell its shares at a discount "on the theory that outside investors will pay less for a minority stake in a close corporation because of their inability to control management"). 
with a discount, out with a discount." Each purchaser of shares, quite naturally, is only willing to pay for what she expects to get.

Under these circumstances, if minority shareholders obtain a pro rata share of a control premium, they receive a windfall for which they did not pay, and to which they had no reasonable expectation. That gain, of course, results in a corresponding and equally unjustifiable loss for the controlling shareholder.

\section{B. The Pro Rata and Expectancy Arguments}

There are basic assumptions of equality of treatment in most areas of corporate law. Since Sterling v. Mayflower Hotel Corp., ${ }^{121}$ the Delaware courts have held that majority shareholders owe a fiduciary duty to the minority when they exercise control over the corporation. ${ }^{122}$ Victor Brudney and Marvin Chirelstein famously argued for a sharing of the gains in a parent-subsidiary merger, by analogizing the parent to a trustee who is required to allocate benefits fairly between multiple trusts. ${ }^{123}$ The rule they suggested was a pro rata sharing of the gains obtained in a merger ${ }^{124}$-a rule that has not, to our knowledge, been expressly adopted by any court. ${ }^{125}$ Later Delaware cases have suggested that parent corporations owe a duty of "entire fairness" to the public shareholders of the subsidiary and that this consists of both fair dealing and fair price, but have thus far failed to distinguish fair price in these circumstances from the appraisal valuation. ${ }^{126}$

12193 A.2d 107 (Del. 1952).

${ }^{122}$ See e.g., Parfi Holding AB v. Mirror Image Internet, Inc., 817 A.2d 149, 160 (Del. 2002) ("The right to vindicate breaches of fiduciary duty inflicted by a majority stockholder on the minority is a central doctrine of Delaware law." (citing Sterling, 93 A.2d at 109-10)); Citron v. E.I. DuPont de Nemours \& Co., 584 A.2d 490, 500 (Del. Ch. 1990) (" $[W]$ here a majority stockholder stands on both sides of a challenged transaction, it has the burden of demonstrating . . that the transaction was entirely fair to the minority." (citations omitted)).

${ }^{123}$ Victor Brudney \& Marvin A. Chirelstein, Fair Shares in Corporate Mergers and Takeovers, 88 HARV. L. REV. 297, 319-22 (1974). Valuation difficulties in making such a rule operational, among other things, may explain why it has not been adopted.

I24. at 321 .

${ }^{125}$ The Maine Supreme Judicial Court, however, approved lowering the weight accorded market value in a "Delaware Block" method appraisal, citing Brudney \& Chirelstein's concerns that "an acquiring parent corporation which occupies the position of a majority shareholder" may have nonpublic information about future values not reflected in current market prices. In re Valuation of Common Stock of Libby, McNeill \& Libby, 406 A.2d 54, 64 (Me. 1979) (citing Brudney \& Chirelstein, supra note 123, at 305).

${ }^{126}$ Weinberger v. UOP, Inc., 457 A.2d 701, 704 (Del. 1983) ("While the present state of these proceedings does not admit the plaintiff to the appraisal remedy per se, 
Assumptions of equal treatment are relaxed in certain areas because of a need to eliminate minority vetoes and provide for corporate flexibility. Those approaching the problem from an economic and property rights perspective have argued that unequal sharing is efficient because it encourages value-creating control transactions. ${ }^{127}$ Some commentators have argued that the classic management leveraged buyout (MBO) requires such a sharing. ${ }^{128}$ This is in part because an MBO may involve management's seizure of a corporate opportunity under conditions where managers have nonpublic information about values. ${ }^{129}$ But, the evidence thus far does not suggest that MBOs involve any systematic abuse of shareholders, because the premiums paid to public shareholders are of the same magnitude as those paid in third-party transactions. ${ }^{130}$ Additionally, since all public shareholders share in such a premium, there is little reason to argue for an additional premium above this price. Accurately measuring the gains to the managers, however, is impossible. Indeed, in many cases bidders have overestimated value, and paid public shareholders too much. ${ }^{131}$ This illustrates the extreme difficulties in measuring fairness in going private transactions.

\section{The Evidence from Contracts}

In the case of mergers, particularly cash-out mergers following takeover bids, there is ample evidence of what shareholders regard as a fair price ex ante, as opposed to the ex post positions taken in

the practical effect of the remedy we do grant him will be co-extensive with the liberalized valuation and appraisal methods we herein approve for cases coming after this decision.").

${ }^{127}$ See, e.g., Easterbrook \& Fischel, supra note 116, at 704 (describing conditions under which the directors' duty to maximize wealth may require unequal distributions); Hermalin \& Schwartz, supra note 107, at 360-64 (arguing that the law should award pre-investment market price in appraisals).

${ }^{128}$ See, e.g., John C. Coffee, Jr., Transfers of Control and the Quest for Efficiency: Can Delaware Law Encourage Efficient Transactions While Chilling Inefficient Ones?, 21 DEL. J. CORP. L. 359, 412 (1996) (noting that some see MBOs "as the product of a desire by one group to exploit a business opportunity that requires the elimination of the minority").

${ }^{129}$ Id. at 408-12 (suggesting that value may differ from market price based on nonpublic information which, if publicly available, would cause the market price to more clearly reflect the manager's private knowledge).

${ }^{130}$ See Jeffry Davis \& Kenneth Lehn, Information Asymmetries, Rule 13e-3, and Premiums in Going-Private Transactions, 70 WASH. U. L.Q. 587, 594-603 (1992) (presenting evidence that MBOs do not deprive shareholders of higher premiums).

${ }^{131}$ See generally Black, supra note 17. 
appraisal proceedings. This evidence shows a strong reliance on markets and shareholder processes: any price agreed to by a specified majority of the shareholders in an uncoerced setting is deemed to be a fair price at which the remaining shareholders can be cashed out. ${ }^{132}$ To this end, hundreds and probably thousands of firms have adopted "shark repellent" amendments to their charters. ${ }^{139}$ The most common form of shark repellent provides that in the event of a takeout merger with an "interested stockholder," a specified percentage of all shares must approve the merger. This percentage is usually between twothirds and ninety-five percent. ${ }^{134}$ Sometimes, however, this supermajority rule is relaxed in response to one of two possible events: (1) pre-takeover approval of the merger by the incumbent directors, who presumably have fiduciary obligations to ensure that all shareholders are treated fairly, or (2) the payment of a "fair price" to the remaining public shareholders, typically defined as the highest price paid for shares of the target by the successful bidder within the past two years. ${ }^{135}$ These charter amendments have required shareholder approval, suggesting that shareholders believe this provides adequate protection of their interest in the company.

If shareholders vote in favor of such amendments and agree to accept prices consented to by a majority of their fellow shareholders, why is a price determined in this manner not fair to them in the context of an appraisal proceeding? To avoid this inconsistency, any takeout merger following the acquisition of control at the same price as the control transaction should be presumed fair, absent a showing

${ }^{132}$ The widespread employment of "shark repellent" charter amendments that assure minority public shareholders that they will receive at least as much as the tendering majority of shareholders received is evidence of a willingness to accept the same price the majority found attractive. William J. Carney, Shareholder Coordination Costs, Shark Repellents and Takeout Mergers: The Case Against Fiduciary Duties, 1983 AM. B. FOUND. RES. J. 341, 373-82 (1983) ("[Fair price rules] are designed to assure nontendering shareholders a 'fair' price in the event of a takeout merger.").

${ }^{33}$ John C. Coates IV, Takeover Defenses in the Shadow of the Pill: A Critique of the Scientific Evidence, 79 TEx. L. REV. 271, 359-65 app. C (2000), cites fifteen separate event studies of these amendments, some of which examine as many as 763 amendments. Because of potential overlap in these studies, it is impossible to determine the total number of adopting firms without examining the database for each study. For a description of the varieties of shark repellent amendments, see Carney, supra note 132, at 373-82; see generally William J. Carney, Two-Tier Tender Offers and Shark Repellents, 4 Midland CORP. Fin. J. 48 (1986).

${ }^{134}$ Carney, supra note 102, at 51; Carney, supra note 132, at 373-82.

${ }^{135}$ Carney, supra note 102, at 51-52; Carney, supra note 132, at 380. For an example of such an amendment see WILlIAM J. CARNEY, MERGERS AND ACQUISITIONS: CASES AND MATERIALS app. B (2000). 
that the shareholders who tendered in the first step were deceived. This would parallel the treatment given in other contexts, such as the Delaware Supreme Court's presumption of a fair price if a merger is conditioned on approval by a majority of the informed public minority shareholders.

The absence of a successful takeover bid during a freeze-out of minority shareholders by a long-term majority shareholder raises a different issue. In this situation, there is no evidence of any probability of a takeover bid that would create a control premium. Indeed, the majority shareholder would not require ownership of all stock in order to obtain a control premium; it could simply sell its existing shares. What remains, then, is a suspicion that a majority shareholder may find a freeze-out is to its benefit because it creates, in a sense, invisible wealth transfers from the minority. This is a slim reed on which to build a conclusion that "intrinsic" values will always be in excess of market prices.

\section{THE ForgotTEN STATUTE: INTERPRETATIVE CONFLICTS}

We now move to a discussion of why the Delaware Supreme Court's stance conflicts with the appraisal statute and other aspects of Delaware law. Regardless of whether one accepts the previous arguments made in this Article, these conflicts must be addressed and are not easily resolved absent a rejection of the general use of control premiums in appraisal proceedings.

\section{A. Excluding the Gains from the Transaction: Warmings About Speculation}

Delaware's appraisal statute, section 262(h), commands the court to determine the fair value of "shares ... exclusive of any element of value arising from the accomplishment or expectation of the merger or consolidation ...."137 This rule implicitly recognizes that by exiting the firm, the shareholder is not bearing the risks of the merged firm and should not share in the anticipated rewards from its success. ${ }^{138}$

${ }^{136}$ See Weinberger v. UOP, Inc., 457 A.2d 701, 703 (Del. 1983) ("[W] here corporate action has been approved by an informed vote of a majority of the minority shareholders, we conclude that the burden entirely shifts to the plaintiff to show that the transaction was unfair to the minority.").

${ }^{137}$ DEL. CODE ANN. tit. 8, $\$ 262($ h) (2001).

138 Additionally, this rule is efficient in terms of providing the risk-takers who purchase control with the marginal gains from the transaction. For a further discussion of 
In Weinberger v. UOP, Inc., the Delaware Supreme Court may have narrowed the scope of the statutory language by holding that "[o]nly the speculative elements of value that may arise from the 'accomplishment or expectation' of the merger are excluded." ${ }^{139}$ The courts thereafter have focused on the term "speculative" rather than the phrase "merger or consolidation" in determining what aspects of value to exclude. ${ }^{140}$ Regardless of whether one agrees with this aspect of the Weinberger decision, it is clear that the courts may not make speculative determinations of value. Also, Delaware courts generally have been careful to distinguish between values created by the announced merger and the value of the pre-merger firm. This is true even where a new controlling shareholder has begun to implement value-creating strategies in anticipation of total ownership after the merger. ${ }^{141}$

Application of a control premium in freeze-outs involves speculation about aspects of value that might be created by a hypothetical merger. In such cases, the parties and benefits of the hypothetical merger are not known and, therefore, cannot be directly analyzed. Under these circumstances, it is difficult to square the use of control premiums with the cautionary language of the appraisal statute and its interpretation by Weinberger and other decisions. The message of both of these authorities militates against such a device. Indeed, the best evidence that no control premiums are currently unrecognized in the stock's price is the fact that no transfer of control is taking place in the class of freeze-out mergers that we address here.

\section{B. The Stock Market Exception}

Awarding a control premium in an appraisal proceeding unjustifiably treats cash and stock mergers differently in terms of value received. Like many other states, Delaware provides an exception from appraisal rights where the consideration given to the minority shareholders is stock in another publicly held corporation. Under these

efficiency gains under the Delaware statute, see Hermalin \& Schwartz, supra note 107, at 355 .

139457 A.2d at 713.

${ }^{140}$ See, e.g., Paskill Corp. v. Alcoma Corp., 747 A.2d 549, 550 (Del. 2000) (holding that speculative tax liabilities and expenses should be excluded from net asset value); Cede \& Co. v. Technicolor, Inc., 684 A.2d 289, 297 (Del. 1996) (citing Weinberger, 457 A.2d at 713, for the rule that only "speculative elements of value" may be disregarded).

${ }^{141}$ See, e.g., Cede, 684 A.2d at 298-99 (holding that value added prior to a cash-out is still attributable to the going concern). 
circumstances, shareholders who do not like the deal can follow Bayless Manning's advice and simply sell their shares into the market. ${ }^{142}$ If, as the Delaware courts now believe, the market price of all companies reflects a minority discount, then the minority shareholders who sold into the market would receive less than the full value of their shares. ${ }^{143}$

Manning argued that appraisal was unnecessary to protect minority shareholders in mergers. In his view, the expense and delay of the remedy were so great that the net proceeds to shareholders were unlikely to exceed what could be obtained by selling into the market. ${ }^{144}$ Manning's radical idea was taken up with remarkably little debate or discussion. Indeed, Professor Ernest Folk's recommendations to the Delaware Corporation Law Revision Committee adopted Manning's proposals without attribution, ${ }^{145}$ and they were adopted in the 1967 revision of the Delaware General Corporation Law. ${ }^{146}$ The Model Act followed suit in 1969, although the Committee on Corporate Laws reversed direction in 1978, when it apparently felt that generally "depressed stock prices did not provide frozen-out shareholders with a "fair" price. ${ }^{147}$ Section 61 of the General Corporation Law of Delaware's Revised Code of 1935 (Chapter 65) provided that upon merger

142 See Bayless Manning, The Shareholder's Appraisal Remedy: An Essay for Frank Coker, 72 YALE L.J. 223, 238 (1962) ("[I]n the remote event that [the shareholder] has thought about the transaction and reacted against it, he simply sells his shares.").

${ }^{143}$ Because the stock price will decline on news of a merger that is disadvantageous for public shareholders, this provides essentially no protection for public shareholders who receive shares in another publicly held corporation. For works noting this observation, see Daniel R. Fischel, The Appraisal Remedy in Corporate Law, 1983 AM. B. FoUnD. RES. J. 875, 885; Randall S. Thomas, Revising the Delaware Appraisal Statute, 3 DEL. L. REV. 1, 21 (2000); Robert B. Thompson, Exit, Liquidity, and Majority Rule: Appraisal's Role in Corporate Law, 84 GEO. L.J. 1, 29 (1995).

${ }^{144}$ Manning, supra note 142, at 260-62.

${ }^{145}$ ERnest L. FOl.K III, REVIEW OF THE DELAware CORPORATION LAW 198-200 (1968).

${ }^{146}$ DEL. CODE ANN. tit. 8, $\$ 262$ (b) (2001) (originally enacted as $\$ 262(k)$ ). Professor Folk's post-adoption commentary is equally succinct, asserting that "if the appraisal remedy provides a judicially created market for dissenting stockholders, such a device is unnecessary where there is already a substantial trading market ...." ERNEST L. Folk III, The Delaware General Corporation law: A COMMENTARY and ANALYSIS $391 \mathrm{n} .152$ (1972). This account is somewhat of a simplification. For a more detailed account, see Randall S. Thomas, Revising the Delaware Appraisal Statute, 3 DEL. L. REV. 1, 7-9 (2000), which describes the 1967 Folk revisions and the market-out exception.

${ }^{147}$ Alfred F. Conard, Amendments of Model Business Corporation Act Affecting Dissenters' Rights (Sections 73, 74, 80 and 81), 33 Bus. LAW. 2587, 2595 (1978). This was an error, because minority shareholders frozen out in depressed markets could replace their shares with stocks priced at similarly depressed levels. 
and written demand, dissenting shareholders shall be paid the value of their stock at the date of merger. ${ }^{148}$ It is hardly surprising that in its initial decisions in this area, the Delaware Supreme Court did not consider the issues of control premiums or minority discounts. In 1950, the year in which Tri-Continental Corp. v. Battye ${ }^{149}$ was decided, the control premium phenomenon, in the context of sales of control, was barely on the horizon (although it would generate much discussion in the following two decades). ${ }^{150}$ In Tri-Continental, the court's statement that shareholders should be paid the value of their stock simply meant that they were not entitled to a valuation based upon their pro rata share of the value of the underlying firm assets as if liquidation occurred. The issue of whether shares could have different values under different circumstances never arose, except to reject the use of liquidation values. ${ }^{151}$

The market exception approach, adopted in 1967, did not appear to change radically what dissenting shareholders would obtain. It simply made it clear that dissenting shareholders would receive the market value obtainable at the time of sale, and no more-an amount not noticeably different from the "value of their stock on the date of

${ }^{148}$ DEL. REV. CODE $\$ 2093$ (1935).

14974 A.2d 71 (Del. 1950).

${ }^{150}$ See, e.g., Perlman v. Feldmann, 219 F.2d 173, 178 (2d Cir. 1955) (“[I]n a time of market shortage, where a call on a corporation's product commands an unusually large [control] premium ... we think it sound law that a fiduciary may not appropriate to himself the value of this premium."); William D. Andrews, The Stockholder's Right to Equal Opportunity in the Sale of Shares, 78 HARV. L. REV. 505, 506 (1965) (asserting that whenever a controlling block of shares is sold, minority shareholders should receive an equal opportunity to sell their shares under equivalent terms); David C. Bayne, A Philosophy of Corporate Control, 112 U. PA. L. REV. 22, 67 (1963) ("Corporate control is truly a corporate asset. All shareholders are entitled to share equally in this asset. No individual or group ... may lawfully appropriate this asset solely for personal benefit."); Robert W. Hamilton, Private Sale of Control Transactions: Where We Stand Today, 36 CASE W. RES. L. REV. 248, 250 (1985) (examining academic writing between 1930 and 1970 which asserted that "'control' is a corporate asset" and that all shareholders should share the premium proportionately); Richard W. Jennings, Trading in Corporate Control, 44 CAL. L. REV. 1 (1956) (arguing that a controlling shareholder should relinquish any premium from the sale of the control block).

${ }^{151}$ See Bell v. Kirby Lumber Corp., 413 A.2d 137, 140-42 (Del. 1980) (applying the rule established in Tri-Continental). It is strange to speak of asset values as somehow separate from firm values, when financial assets, such as timber, only represent value based upon the discounted value of the cash flows they will produce, but this is how the Delaware courts have chosen to speak of them. This view arises because of TriContinental's holding that firms are to be valued on the basis of their going concern value before the merger announcement, rather than on their liquidation value. $I d$. at $141-42$. 
the merger."152 Those shareholders that did not dissent and that received shares in another publicly traded entity would thus be treated quite differently. It is puzzling that no Delaware court has ever noted this remarkably disparate treatment.

\section{Section 155 and "Fair Value"}

We note one additional conflict in Delaware corporate law relevant to this discussion. Section 155 of the Delaware Corporations Code governs the issuance and disposition of fractional shares and provides that "[a] corporation may, but shall not be required to, issue fractions of a share. If it does not issue fractions of a share, it shall ... pay in cash the fair value of fractions of a share as of the time when those entitled to receive such fractions are determined . . .."153

In a recent reverse stock split to eliminate small holdings, Avaya, Inc. proposed to pay holders of fractional shares the average market price of their shares over the ten-day period preceding the transaction. ${ }^{154}$ In approving the proposal as fair, Chief Justice Veasey stated:

The corporation owes its cashed-out stockholders payment representing the "fair value" of their fractional interests. The cashed-out stockholders will receive fair value if Avaya compensates them with payment based on the price of Avaya stock averaged over a ten-day period preceding the Proposed Transaction. While market price is not employed in all valuation contexts, our jurisprudence recognizes that in many circumstances a property interest is best valued by the amount a buyer will pay for it. The Vice Chancellor correctly concluded that a well-informed, liquid trading market will provide a measure of fair value superior to any estimate the court could impose. ${ }^{155}$

${ }^{152}$ We note that this approach antedated widespread understanding of ECMH, so it is unlikely that Manning, Folk, or the drafters of the Delaware Act and the Model Act recognized that an announcement of a bad deal for public shareholders would immediately depress the market price of their shares.

${ }^{153}$ DEL. CODE ANN. tit. $8, \$ 155$ (2001) (emphasis added). In the alternative, the corporation may either "arrange" for the disposition of fractional shares (by, for example, acting as an intermediary to package the fractional interests into marketable shares) or issue scrip or warrants that are redeemable when totaling a full share. Id.

${ }_{154}$ Applebaum v. Avaya, Inc., 812 A.2d 880, 884 (Del. 2002). Under the proposal, not all fractional shares would be cashed out; Avaya would immediately thereafter engage in a mirror-image stock split. That is, after a 1-for-30 reverse stock split the company would transact in a 30 -for-1 stock split, in which all shareholders holding a whole share or more would participate. Id at 883 . Those shareholders who lacked the minimum number of shares would then be cashed out. Id. at 883-84.

${ }^{155} I d$. at 889-90 (footnotes omitted). 
The Avaya opinion distinguished its use of market value as the exclusive basis for determining fair value in a fractional shares case under section 155 from the same exercise in appraisal cases, on the basis that the appraisal statute instructs that "[i]n determining such fair value, the Court shall take into account all relevant factors." ${ }^{156}$ We simply observe that in an efficient market, absent information about some market failure, market price is the only relevant factor. ${ }^{157}$ The result is that under section 155, "fair value" means "market value" and under section 262, "fair value" cannot mean "market value." This result is true even if that market value is based on a "well-informed, liquid trading market [that] will provide a measure of fair value superior to any estimate the court could impose."

Probably the most interesting issue that the Avaya decision raises is the distinction in procedure that the court has created between a reverse stock split to eliminate small holdings and the use of a freezeout merger to accomplish the same end. Such a distinction is not supported by the statutory language and may have unintended effects. Future majority shareholders may be well advised to choose the reverse stock split as the most efficient method of eliminating minority shareholders. If they so choose, then the control premium problem of appraisal will become moot, since all freeze-outs will be structured as reverse stock splits. A more consistent jurisprudence would abandon formalistic distinctions and make both freeze-out methods available by relying on market values, unless plaintiffs could establish to the courts' satisfaction that market values were unreliable in a particular instance, and demonstrate the direction and magnitude of the error.

\section{CONCLUSION}

Modern financial theory has provided many insights into value, including ECMH and portfolio theory. These models do not support the current use of control premiums in appraisal proceedings. Since the Delaware courts are entrusted to determine the "fair value" of a dissenter's shares, the Delaware courts should bring clear consideration of current financial knowledge to the appraisal process. Even if this knowledge is set aside, confused, or simply rejected, so that one

${ }^{156}$ DEL. CODE ANN. tit. 8, $\$ 262(\mathrm{~h})$ (2001), cited in Avaya, 812 A.2d at 889 n.28.

${ }^{157}$ We assume that Delaware's "independent legal significance" doctrine will continue to be applicable.

${ }^{158} 812$ A.2d at 890. 
assumes that minority discounts are generally reflected in market prices, a shareholder is fairly compensated when paid such a discounted value because the shareholder can easily replace such a discounted stock with another equally discounted stock. Furthermore, when the current use of control premiums is highlighted against the backdrop of the structure and language of the Delaware appraisal statute and other aspects of Delaware corporate law, a tension is created that is not easily rectified absent rejection of control premiums. We suggest that the Delaware Supreme Court rethink its position on control premiums so that dissenting shareholders are fairly compensated without unnecessarily transferring value from the majority or creating statutory conflicts. 